\title{
Financial Market Development and Income Distribution Inequality in the Emerging Markets
}

\author{
Dingli Xi ${ }^{1}$ \\ ${ }^{1}$ Faculty of Business, Economics and Law, School of Economics, The University of Queensland, Australia \\ Correspondence: Dingli Xi, Faculty of Business, Economics and Law, School of Economics, The University of \\ Queensland, Australia.
}

Received: September 3, 2019

Accepted: September 18, 2019 Online Published: October 8, 2019

doi:10.20849/abr.v4i3.653

URL: https://doi.org/10.20849/abr.v4i3.653

\begin{abstract}
The disruptive effects of the subprime financial crisis have raised new global concerns toward the increasing income distribution inequality. Nowadays, it has become one of the mainstays of public and scientific discourse around the world. Theoretical financial Kuznets curve suggests that the relationship between financial market development and income distribution inequality follows an inverted U-shaped pattern. However, current literature failed to support this hypothesis. The expansion of the financial market truly provides more relative opportunities for the poor which benefits the equalization. But those advantage opportunities are likely to be captured by some specific groups instead of all population. The majority literature on this academic field focus on developed countries with cross-sectional and panel data analysis that providing controversial results. They emphasize the financial development as a consequence of economic growth without deep analysis of the financial market development as an independent entity in determining the inequality. This study proposes to use a more comprehensive and rigorous method to identify the direct relationship between financial market development and income distribution inequality in 10 most typical emerging markets. Both short-run and long-run impacts of financial market development on income distribution inequality are examined and defined by utilizing time-series data and error-correction modelling technique. By providing a better understanding of the relationship, the findings of the research would make contributions to financial market policy adjustments in developing countries.
\end{abstract}

Keywords: financial market, income distribution, Kuznets Curve

\section{Introduction}

The widening income inequality has always been one of the most troubling developments around the world (Baiardi \& Morana, 2018; Fawaz, Rahnama, \& Valcarcel, 2014; Zalewski \& Whalen, 2014). Although global income inequality has improved slightly since the 21 st century, it still aroused world-range interests and concerns due to the disruptive effects of the subprime financial crisis (Hillebrand, 2008). Despite of the dominant academic viewpoint since the early 1970s that the income distribution inequality was mainly driven by the economic growth and technology development, the world-wide occupy movements in recent years elucidate an explicit public attitudes regarding the income disparity and financial development (Anand \& Segal, 2017).

Arguably, the emerging countries have achieved a great economic success over the past few decades. The developing countries like China and India now representing a highly heterogenous economic group in the world economy in terms of population, economic size and performances (Meschi \& Vivarelli, 2009). These new emerging countries are expected to play a more essential role worldwide both politically and economically in the foreseeable future. However, the increasing income distribution inequality is always a great concern for all emerging countries (Iniguez-Montiel, 2014). As many developed countries have experienced, the rapid economic growth not only bought the wealth and prosperity but also the great challenge to the social equality. Historical data suggests that the inequality levels in emerging economies as a whole has experienced a steep increase over the past three decades, which maintaining a higher level compared to the OECD (Organization for Economic Corporation and Development) average (Hillebrand, 2008). In some extreme cases like Brazil and South Africa, the income inequality levels are almost as twice as greater than the former 30 years (Meschi \& Vivarelli, 2009). Therefore, the study of the inequality in those emerging economies requires greater attention not only due to their own social welfare and economic development but also their significance in relation to the world economy. 
The relationship between financial development and economic growth has firmly established in the wide literature scale (Arora, 2011; Bijlsma, Kool, \& Non, 2018; Fawaz et al., 2014; Samargandi, Fidrmuc, \& Ghosh, 2015; Shin, 2012; Yu, Hassan, \& Sanchez, 2012). The high growth and development of financial sector has always seen as a great catalyst for sustaining economic growth and achieving economic prosperity in previous studies (Bijlsma et al., 2018). The well-developed financial sector could stimulate the capitalization of the country which providing easy access for poor population to the financial resources (Baiardi \& Morana, 2018). Economists generally believe that a prudential developed or proper regulated financial sector enhance the income distribution equalization. However, despite of the development level of financial sector within countries, contradictory results have been found in the literature when studying the cross-sectional country performances. The theoretical connection between financial market development and income distribution inequality seems not holding well with ambiguous and elusive empirical evidences.

This research proposes to use a more comprehensive and rigorous method to identify the direct relationship between financial market development and income distribution inequality. Most papers that examined the relationship were using panel data approach, while the time-series data analyses are comparably rare. Moreover, the majority time-series studies in this area have focused only with the individual countries. This study will come across time series data in 10 most typical emerging countries. Both long-run and short-run impacts of financial market development on income distribution will be examined and defined by error-correction modelling technique. Additionally, by providing a brief understanding of the relationship, this study will be able to contribute new conclusion to existing literature for researchers or policy makers.

\section{Aims, Objectives and Research Questions}

\subsection{Aims}

The main aim of this study is to prove the existence of the direct relationship between financial market development and income distribution inequality in emerging countries. The earlier academic viewpoint in this field suggests that the increasing income distribution inequality is an inevitable consequence of the economic growth or technology advance (Fawaz et al., 2014). More recent researches on the association between financial market development and income distribution inequality are relatively rare with no deep analysis of emerging economies (Bahmani-Oskooee \& Zhang, 2014). By applying the empirical evidence observed in emerging countries, this study aims to verify that the financial market development is playing a crucial role in determining the income distribution inequality. The overall effects will be applied to provide a more comprehensive and system explanation of the inequality in emerging countries. Additionally, by providing the explanation, the research aims to contribute new knowledge to existing literature review for researchers and relevant interest parties.

\subsection{Objectives}

In accordance with the aims of the research, three research objectives will be proposed to obtain the final goal of the study. Thoughtful considerations of the value and significance of current literature will be added for proposing the objectives. The empirical findings will be used in conducting the research with comparable attributes. However, the primary objective of this study is to find the relationship between financial market development and income distribution inequality in emerging markets. By utilizing the time-series data analysis and bound-testing approach, this study is able to define the relationship.

The second objective is to evaluate the possible impact of this relationship. Theoretical literature suggests that the financial market development will raise the income inequality in the early stage, but it will eventually lead to a more equal income distribution after crossing certain economic threshold (Shahbaz, Loganathan, Tiwari, \& Sherafatian-Jahromi, 2014). Nevertheless, widely empirical literature observed that the financial development is not always following the proposed inverted U-shape. In general, the relationship between financial market development and income inequality may be subject to nonlinearity (Jerzmanowski \& Nabar, 2013). However, by using time-series data analysis, we are able to identify whether the link is negative or positive in the emerging markets.

Moreover, previous studies emphasis that the financial market as a factor of economic growth, without deep analysis of the financial market as an independent entity. The selected explanatory variables in measuring financial development are largely biased to the performance of economy as a whole. Therefore, the final objective of this research is to analyse whether the estimated relationship in emerging markets is coincided with the proposed theoretical literature. By selecting different explanatory variables compared to the previous studies, other possible impacts of economic growth on inequality are able to be eliminated. Overall, a more intuitive understanding about this relationship to the existing literature could simultaneously assists policy makers in 
preventing the possible potential crisis due to the mismanagement of the financial sector.

\section{In the light of the objectives mentioned above, we are targeting to answer the following questions:}

2.21 Is there any direct relationship between financial market growth and income distribution inequality?

2.22 What is the possible impact of the income distribution inequality due to the financial market growth?

2.23 Is the inverted U-shaped Kuznets Curve applicable in interpreting the relationship?

\section{Literature Review}

Contradictory results have been perceived in the previous literature review when exploring the relationship between financial development and income distribution inequality. The theoretical concern in exploring the connection is still unclear. Generally, the outcome of literature review on the relationship is divided to two categories. The first finding is that the financial market development could increase the income distribution inequality to some extent. (Arora, 2011; Menyah, Nazlioglu, \& Wolde-Rufael, 2014; Shahbaz, Bhattacharya, \& Mahalik, 2017; H. Zhang, 2016; H.-w. Zhang, Chen, \& Zhang, 2011). The second finds that a well-developed and appropriately managed financial market could enhance the economic growth and reduce the income distribution inequality (Bahmani-Oskooee \& Zhang, 2014; Baiardi \& Morana, 2018; Kiendrebeogo \& Minea, 2016; Shahbaz et al., 2014).

One of the most widely studied theoretical explanations in this academic field has been the financial Kuznets curve (Arora, 2011). It is proposed as an extension of economic Kuznets curve that advanced by Simon Kuznets in the 1950s and 1960s based on the historical data observed from Germany, England and the statistical regularities (Cheng \& Wu, 2016). The financial Kuznets curve literature suggests that the income inequality and financial development can be presented by an inverted-U shape correlation. With the growth of financial sector, countries will firstly suffer from increasing inequality and then followed by a declining trend after the growth across a certain threshold (Shahbaz et al., 2014). However, the most significant gap for this hypothesis has come to light over time. The proposed invented- $U$ shape relationship is not fully applicable to all countries in very different developing stages (H.-w. Zhang et al., 2011). Due to the economic complexity, many researchers conclude that financial development and income distribution does not necessarily follow the financial Kuznets hypothesized pattern (Abosedra, Shahbaz, \& Nawaz, 2015; Cheng \& Wu, 2016; Moosa, 2017; Zalewski \& Whalen, 2014; H.-w. Zhang et al., 2011).

With the intention to explain the relationship, Baiardi and Morana (2018) conducted their researches based on Euro area, found that the developing financial sector improved the income distribution equality during the last few decades. They noted that a well-functioning financial system with continuous improvement is critical on promoting the equalized income dispersion. Strong statistical evidence has been observed which indicates that financial development contributes to a relatively low per-capital income level when come across the threshold hypothesis proposed by the financial Kuznets curve. Similarly, Bahmani-Oskooee and Zhang (2014) conducted a study through time series data analysis in 17 developed countries. They concluded that the financial market provides opportunities for individuals to convert private saving to investment, which could reduce the inequality. The growth of financial market strengthens the capacity for the poor to borrow funds which could enhance their personal qualities, education, and business skills. Nevertheless, a major limitation for both of these studies is that their researches were only based on developed countries where the financial system is prudential developed and proper regulated. The financial sector in emerging countries is relatively not well-regulated compared to the developed countries (Shahbaz et al., 2017). The results, therefore, may not be applicable in explaining world inequality as a whole.

In the case of developing countries where the financial system maturity is still behind the developed countries, Kiendrebeogo and Minea (2016) in their study of CFA Franc Zone (Central Africa Countries) concluded that the financial market development has a positive impact on poverty reduction after crossing the threshold, which gives a solid evidence for the existence of the notion of financial Kuznets curve. However, a drawback for their study is that they may suffer from a data collection bias due to the subprime financial crisis and sovereign-debt crisis. Shahbaz et al. (2014) conducted their study in Iran, suggest that economic growth blocks the income distribution, whereas the financial development equalize the distribution. The expansion of the financial market can provide numerous opportunities for the poor. Four factors have been defined, including easy access to capital markets, technological innovation, resources reallocation and human capital development. A limitation for their studies is that the sample area is limited to their respective research countries with no broader research of the phenomenon.

On the opposite side, conflicting results have been observed in suggesting that the financial development directly 
caused the income inequality. Zhang (2016) in her study of the one-way impact of the wealth inequality and financial globalization noted that the degree of the income inequality and the level of financial market development are exogenous. It is researched that income inequality can be regarded as a consequence of financial development. The worldwide financial development is directly associated with the rising distribution inequality. Moreover, Shahbaz, Bhattacharya and Mahalik (2017) in their study of finance and income inequality based on Kazakhstan did found that the there is a bidirectional causality exists between the finance and inequality. Conversely, they observed that the association between financial development and income inequality is actually following a U-shaped pattern. They concluded that the financial development in the early stage can equalize the income distribution. They also asserted that the threshold effect exists where the income inequality had increased after the finance sector growth to a certain level.

For the purpose of explaining the controversy results, Arora (2011) argues rural and urban areas should be considered separately when studying the inequality. They found that the inequality in rural area is not as responsive as that in urban areas due to limited financial development. However, a limitation for his study is that he is not unable to separate the firms, household and bank credit variables when measuring the financial development. These three credit variables are highly correlated. Thinking from the other side, Lim and McNelis (2016) indicated the reason, that countries are at different development periods. They found the evidence that financial development is only beneficial for economic entities that are relatively capital-intensive. The redistributive effects of the increasing marginal productivity of labour promote higher income inequality only for countries which reach the capital intensive of production and growth income. The financial development is likely to benefit both income growth and equality only when the financial development crosses the critical threshold in capital intensity.

\section{Methodology}

\subsection{Data Sources}

The sample composes 10 most representative emerging markets including China, India, China, Brazil, South Africa, Argentina, South Korea, Poland, Turkey, Mexico and Indonesia. The data covers the period dated from the year 1991 to 2006. The selected period begins with the year 1991, because Poland and China did not have any established stock market before 1991 due to former political ideology. Meanwhile, the data before the subprime financial crisis is not as valuable as in 2007 due to the instability and volatility.

The main source of the data applied in this study will be based on the secondary sources due to the budget constraints and time limitations. The data in measuring financial development will be obtained from the Global Development Finance data bases and World Bank's World Development Indicators and the International Monetary Fund's International Financial Statistics database. The data for Inequality estimation will be extracted from the University of Texas Inequality Project's Estimated Household Income Inequality Data Set. Moreover, STATA software will be used in the process of constructing the data and undertaking the regression.

\subsection{Dependent Variables}

The Gini Coefficient is considered as the only indicator for representing the income distribution inequality as it is a relatively accurate and reliable tool that is widely accepted in the existing literature. The Gini Coefficient permits a feasible direct comparison between different populations and units. (Baiardi \& Morana, 2018). The greater Gini Coefficient captures a higher income distribution inequality within the country (Corrado, 1912). However, a major limitation for using the Gini Coefficient in the study is that the absolute differences of the income are neglected. It is possible that the Gini index measured a rising income inequality despite that the country's absolute poverty or number of people living in poverty is actually declining (Druckman \& Jackson, 2008).

\subsection{Independent Variables}

Four determinants are borrowed from the former literature in order to measure the financial market development. By relating the financial market indicators to the relatively economic size, the real value increase of the financial market in terms of the total GDP is able to be captured. If the poor are benefited more from the financial markets, the income inequality would be relatively low. Only if the rich and those who have better access to financial markets could get the benefit from the financial market development and an increasing income inequality will likely to be captured (Bahmani-Oskooee \& Zhang, 2014). The banking sector development and stock market development are considered as two subgroups to represent the financial market development. The banking sector development consist of (i) the ratio of commercial bank plus central bank assets divide into commercial bank assets (CCB) and (ii) the ratio of private credit by deposit money banks and other financial institutions to GDP 
(CREDIT). The stock market development subgroups consist of two indicators: (i) the ratio of sock value traded as a percentage of GDP (STKVALTRA) and (ii) the ratio of stock market capitalization to GDP (STKMKTCAP) (Soumaré \& Tchana Tchana, 2015).

\subsection{The Model and the Method}

Shahbaz et al. (2014) suggested that converting series into logarithm can provide improved results for the estimation because it reduces the sharpness in time series data. Both short-run and long-run effects of the each variable on Gini coefficient will be included. For the long run approach, since the two-step procedure proposed by Granger (1987) can only have less more than two variables in the model, the ARDL (Autoregressive Distributed Lag) bounds-testing approach developed by Pesaran, Shin and Smith (2001) will, therefore, be used to conduct the study. As such, the following long-run model is adopted:

$$
\text { LnGini }_{t}=\alpha_{0}+\alpha_{1} \text { LnSTKVALTRA }_{t}+\alpha_{2} \text { LnSKMKTCAP }_{t}+\alpha_{3} \text { CAP }_{t}+\alpha_{4} \text { LnCREDIT }_{t}+\varepsilon_{t}
$$

One of the major advantages of ARDL bounds-testing method is that it can extract both long-run and short-run relationships (Bahmani-Oskooee \& Zhang, 2014). In order to estimate the short-run relationship, the equation 1 needs to be specified into an error-correction modelling format in the first place. Pesaran et al. (2001) noted that the key assumption of the ARDL bounds-testing method is that the error terms of the equation must be serially independent. Accordingly, the LM test will be used to apply to detect whether the errors are serially independent or not. Since the model is utilized with an autoregressive structure, it needs to be ensured dynamically stable as well. After incorporating the short-run dynamic adjustment, the following short-run model is able to be obtained:

$$
\begin{aligned}
\Delta \text { LnGini }_{t}=\alpha+ & \sum_{i=0}^{n 1} b_{i} \Delta \text { LnGini }_{t-i}+\sum_{i=0}^{n 2} c_{i} \Delta \text { LnSTKVALTRA }_{t-i}+\sum_{i=0}^{n 3} b_{i} \Delta \text { LnSKMKTCAP }_{t-i} \\
& +\sum_{i=0}^{n 4} c_{i} \Delta \text { LnCCB }_{t-i}+\sum_{i=0}^{n 5} b_{i} \Delta \text { LnCREDIT }_{t-i}+\lambda_{0} \text { LnGini }_{t-1}+\lambda_{1} \text { LnSTKVALTRA }_{t-1} \\
& +\lambda_{2} \operatorname{LnSKMKTCAP~}_{t-1}+\lambda_{3} \text { CCB }_{t-1} \\
& +\lambda_{4} \operatorname{LnCREDIT}_{t-1}+\mu_{t}
\end{aligned}
$$

At last, an F-test will be conducted with new critical values to measure the integrating properties of variables which rules outs the pre-unit-root testing. The variables are assumed to be $\mathrm{I}(0)$ if the computed F-statistic falls below the lower. Under this situation, conclusions can be made that there is no cointegration. Conversely, the variables are perceived to be cointegration if the F-statistic exceeds the upper bound. When the F-statistic falls in-between the bounds, the test is defined to be inconclusive (Pesaran et al., 2001). However, if the bounds-test indicate to the cointegration exist, the short-run effects of each financial market indicators on Gini Coefficient can be successfully estimated.

\section{Significance}

Although there is a growing realization that the financial market development is directly related to the income distribution inequality, the observed results in defining the causality are still controversial. Past research papers have shown that the financial development is more likely to improve the income distribution only in developed countries. The expansion of the financial market is able to provide more relatively opportunities for the poor (Baiardi \& Morana, 2018). Oppositely, the studies based on individual developing countries suggest that the financial development is threatening the inequality because advantages brought by the financial growth are mainly beneficial for specific groups of people (Shahbaz et al., 2014). In general, the current literature however has failed to provide a definitive and comprehensive explanation in identifying the relationship.

Meanwhile, previous studies in this field emphasize the financial development and preference to the economic growth. There is no deep analysis of the financial market development as an independent entity. This research provides new evidence on financial market development and its association towards income distribution inequality. The finding of the research would significantly benefit developing countries in terms of financial market policy adjustments.

Moreover, the major literature in studying this area has focused on the developed countries which mainly based on cross-sectional and panel data analysis. There is no deep understanding on the relationship in emerging 
markets. This study proposes to provide a more comprehensive time-series data analysis which focused on only emerging countries. By identifying the direct influence from financial market development on income distribution inequality, policy makers in emerging countries are able to make possible policies to the financial market in order to maintain the economic prosperity and social stability.

\section{References}

Abosedra, S., Shahbaz, M., \& Nawaz, K. (2015). Modeling Causality Between Financial Deepening and Poverty Reduction in Egypt. Social Indicators Research, 126(3), 955-969. https://doi.org/10.1007/s11205-015-0929-2

Anand, S., \& Segal, P. (2017). Who Are the Global Top 1\%? World Development, 95, 111-126. https://doi.org/10.1016/j.worlddev.2017.02.001

Arora, R. U. (2011). Finance and inequality: a study of Indian states. Applied Economics, 44(34), 4527-4538. https://doi.org/10.1080/00036846.2011.597736

Bahmani-Oskooee, M., \& Zhang, R. (2014). On the impact of financial development on income distribution: $\begin{array}{llll}\text { time-series } & \text { evidence. } & \text { Applied } & \text { Economics, }\end{array}$ https://doi.org/10.1080/00036846.2014.993135

Baiardi, D., \& Morana, C. (2018). Financial development and income distribution inequality in the euro area. Economic Modelling, 70, 40-55. https://doi.org/10.1016/j.econmod.2017.10.008

Bijlsma, M., Kool, C., \& Non, M. (2018). The effect of financial development on economic growth: a meta-analysis. Applied Economics, 50(57), 6128-6148. https://doi.org/10.1080/00036846.2018.1489503

Cheng, W., \& Wu, Y. (2016). Understanding the Kuznets Process-An Empirical Investigation of Income Inequality in China: 1978-2011. Social Indicators Research, 134(2), 631-650. https://doi.org/10.1007/s11205-016-1435-x

Corrado, G. (1912). Measurement of Inequality of Incomes. The Economic Journal, 31(121), 124-126. https://doi.org/10.2307/2223319

Druckman, A., \& Jackson, T. (2008). Measuring resource inequalities: The concepts and methodology for an $\begin{array}{lllll}\text { area-based Gini coefficient. Ecological } & \text { Economics, }\end{array}$ https://doi.org/10.1016/j.ecolecon.2007.12.013

Fawaz, F., Rahnama, M., \& Valcarcel, V. J. (2014). A refinement of the relationship between economic growth and income inequality. Applied Economics, 46(27), 3351-3361. https://doi.org/10.1080/00036846.2014.929624

Granger, C. W. J., \& Engle, R. F. (1987). Co-Integration and Error Correction: Representation, Estimation, and Testing. Econometrica, 55(2), 251-276. https://doi.org/10.2307/1913236

Hillebrand, E. (2008). The Global Distribution of Income in 2050. World Development, 36(5), 727-740. https://doi.org/10.1016/j.worlddev.2007.05.013

Iniguez-Montiel, A. J. (2014). Growth with Equity for the Development of Mexico: Poverty, Inequality, and Economic Growth (1992-2008). World Development, 59, 313-326. https://doi.org/10.1016/j.worlddev.2014.01.011

Jerzmanowski, M., \& Nabar, M. (2013). Financial Development and Wage Inequality: Theory and Evidence. Economic Inquiry, 51(1), 211-234. https://doi.org/10.1111/j.1465-7295.2010.00341.x

Kiendrebeogo, Y., \& Minea, A. (2016). Financial development and poverty: evidence from the CFA Franc Zone. Applied Economics, 48(56), 5421-5436. https://doi.org/10.1080/00036846.2016.1176114

Lim, G. C., \& McNelis, P. D. (2016). Income growth and inequality: The threshold effects of trade and financial openness. Economic Modelling, 58, 403-412. https://doi.org/10.1016/j.econmod.2016.05.010

Menyah, K., Nazlioglu, S., \& Wolde-Rufael, Y. (2014). Financial development, trade openness and economic growth in African countries: New insights from a panel causality approach. Economic Modelling, 37, 386-394. https://doi.org/10.1016/j.econmod.2013.11.044

Meschi, E., \& Vivarelli, M. (2009). Trade and Income Inequality in Developing Countries. World Development, 37(2), 287-302. https://doi.org/10.1016/j.worlddev.2008.06.002

Moosa, I. A. (2017). Does financialization retard growth? Time series and cross-sectional evidence. Applied Economics, 50(31), 3405-3415. https://doi.org/10.1080/00036846.2017.1420899 
Pesaran, M. H., Shin, Y., \& Smith, R. J. (2001). Bounds testing approaches to the analysis of level relationships. Journal of Applied Econometrics, 16(3), 289-326. https://doi.org/10.1002/jae.616

Samargandi, N., Fidrmuc, J., \& Ghosh, S. (2015). Is the Relationship Between Financial Development and Economic Growth Monotonic? Evidence from a Sample of Middle-Income Countries. World Development, 68, 66-81. https://doi.org/10.1016/j.worlddev.2014.11.010

Shahbaz, M., Bhattacharya, M., \& Mahalik, M. K. (2017). Finance and income inequality in Kazakhstan: evidence since transition with policy suggestions. Applied Economics, 49(52), 5337-5351. https://doi.org/10.1080/00036846.2017.1305095

Shahbaz, M., Loganathan, N., Tiwari, A. K., \& Sherafatian-Jahromi, R. (2014). Financial Development and Income Inequality: Is There Any Financial Kuznets Curve in Iran?. Social Indicators Research, 124(2), 357-382. https://doi.org/10.1007/s11205-014-0801-9

Shin, I. (2012). Income inequality and economic growth. Economic Modelling, 29(5), $2049-2057$. https://doi.org/10.1016/j.econmod.2012.02.011

Soumaré, I., \& Tchana Tchana, F. (2015). Causality between FDI and Financial Market Development: Evidence from Emerging Markets. The World Bank Economic Review, 29(suppl 1), S205-S216. https://doi.org/10.1093/wber/lhv015

Yu, J.-S., Hassan, M. K., \& Sanchez, B. (2012). A re-examination of financial development, stock markets development and economic growth. Applied Economics, 44(27), 3479-3489. https://doi.org/10.1080/00036846.2011.577019

Zalewski, D. A., \& Whalen, C. J. (2014). Financialization and Income Inequality: A Post Keynesian Institutionalist Analysis. Journal of Economic Issues, 44(3), $757-777$. https://doi.org/10.2753/jei0021-3624440309

Zhang, H. (2016). Wealth inequality and financial development: revisiting the symmetry breaking mechanism. Economic Theory, 63(4), 997-1025. https://doi.org/10.1007/s00199-016-0977-0

Zhang, H.-w., Chen, W.-g., \& Zhang, J. (2011). Urban-rural income disparities and development in a panel data set of China for the period from 1978 to 2006. Applied Economics, 44(21), 2717-2728. https://doi.org/10.1080/00036846.2011.566197

\section{Copyrights}

Copyright for this article is retained by the author(s), with first publication rights granted to the journal.

This is an open-access article distributed under the terms and conditions of the Creative Commons Attribution license (http://creativecommons.org/licenses/by/4.0/). 